\title{
COMPARAÇÂO DE CINCO PROTOCOLOS PARA EXTRAÇÃO DE DNA E TRIAGEM DE INICIADORES DO TIPO ISSR PARA O GÊNERO Coffea
}

\author{
Fernanda Vargas Valadares ${ }^{1}$ \\ Laricia Olaria Emerick Silva ${ }^{2}$ \\ Rafael Nunes de Almeida ${ }^{3}$ \\ Iris Petronilia Dutra ${ }^{4}$ \\ José Dias de Souza Neto ${ }^{5}$ \\ Monique Moreira Moulin ${ }^{6}$
}

Resumo: O café é uma bebida conhecida e consumida a nível mundial, sendo esta cultura uma grande commodity. O objetivo do estudo foi selecionar o método de extração de DNA mais eficiente e os iniciadores mais polimórficos para a caracterização molecular de cultivares de café do Parque Cafeeiro do Ifes Campus de Alegre. O estudo foi conduzido no Ifes Campus de Alegre com oito cultivares de café, foram testados dois acondicionamentos para folha, congelada ou natural, e cinco protocolos de extração. Após o protocolo escolhido foi feito uma triagem com dez iniciadores ISSR com o intuito de averiguar o polimorfismo gerado. Os protocolos 2, 3 e 5 foram satisfatórios com maiores concentrações de DNA, pelo teste não houve diferença significativa entre o tipo de acondicionamento, e os iniciadores UBC 813, 818, 824, 845 e 859 apresentaram bandas de DNA mais nítidas para os três indivíduos.

Palavras-chave: Análise molecular; Café; ISSR.

\footnotetext{
1 Bacharelado em Ciências Biológicas/Instituto Federal do Espírito Santo Campus de Alegre, Brasil. E-mail: fernanda_valladares@hotmail.com.

2 Licenciatura em Ciências Biológicas/Instituto Federal do Espírito Santo Campus de Alegre, Brasil. E-mail: lariciaemericklara@hotmail.com.

3 Mestrando em Agroecologia/ Instituto Federal do Espírito Santo Campus de Alegre, Brasil. E-mail: rafaelcabral1500@gmail.com.

4 Tecnólogo em Cafeicultural Instituto Federal do Espírito Santo Campus de Alegre, Brasil. E-mail: iriisdutra@gmail.com.

${ }^{5}$ Técnico de Laboratório em Genética e Biologia Molecular/ Instituto Federal do Espírito Santo Campus de Alegre, Brasil. E-mail: jose.neto@ifes.edu.br.

6 Professora Doutora/ Instituto Federal do Espírito Santo Campus de Alegre, Brasil. E-mail: moniquemoulin@gmail.com.
} 